\title{
Topdressing nitrogen fertilization associated with trinexapac-ethyl on industrial quality of oat grains
}

\author{
José Henrique Bizzarri Bazzo ${ }^{1 *}$ (D), Carlos Roberto Riede ${ }^{2}$, Klever Márcio Antunes Arruda ${ }^{2}$, \\ Claudemir Zucareli ${ }^{1}$, Inês Cristina de Batista Fonseca ${ }^{1}$
}

10.1590/0034-737X202168010006

\begin{abstract}
Nitrogen fertilization, besides increasing productivity, can favor the production of well-formed, large, and heavy grains, which are traits valued by the oat processing industry. However, high nitrogen $(\mathrm{N})$ doses may lead to plant lodging, which could be solved by using growth retardant. This study aimed to evaluate the industrial quality of white oat grains cultivated under different nitrogen doses and associated with the growth retardant trinexapac-ethyl in two growing environments. Experiments were conducted in Londrina and Mauá da Serra, PR, Brazil, using the cultivar IPR Afrodite in a randomized block design in a $4 \times 2$ factorial scheme and four replications. Treatments consisted of four topdressing $\mathrm{N}$ doses $\left(0,30,60\right.$, and $\left.90 \mathrm{~kg} \mathrm{ha}^{-1}\right)$ and the application or not of growth retardant. Thousand-grain weight, hectoliter weight, grain index greater than two millimeters, peeling index, and industrial grain yield were evaluated. The effect of $\mathrm{N}$ fertilization and growth retardant on the industrial quality of white oat grains depends on the characteristics of the growing environment. The trinexapac-ethyl application reduces grain quality in Londrina and Mauá da Serra. However, the industrial quality of grains is high in both growing environments when the growth retardant is associated with nitrogen doses.
\end{abstract}

Keywords: nitrogen; Avena sativa L.; lodging; growth retardant; technological quality.

\section{INTRODUCTION}

Nitrogen $(\mathrm{N})$ is one of the quantitatively most essential elements for white oat (Kolchinski \& Schuch, 2004) and an essential element for its growth and development (Mundstock \& Bredemeier, 2001).

Obtaining high yield levels and better industrial quality oat grains can be achieved using the nitrogen fertilization (Ceccon et al., 2004). Oat breeding programs in southern Brazil have developed cultivars more responsive to $\mathrm{N}$ application (Kolchinski \& Schuch, 2002), which allowed a significant increase in yield and especially grain quality.

Kolchinski \& Schuch (2004) worked with four grain white oat cultivars (CTC 5, UFRGS 15, UFRGS 19, and UPF 18) and four topdressing $N$ doses (0, 24, 48, and $73 \mathrm{~kg}$ $\left.\mathrm{ha}^{-1}\right)$ and verified that the increased nitrogen fertilization positively influenced the industrial quality of oat grains.
Thus, $\mathrm{N}$ supply to crops can become a strategy to meet the demands of the food industry, which require wellformed, large, heavy, and uniform grains to achieve high industrial yield (Alves \& Kist, 2010).

However, the use of high $\mathrm{N}$ doses may influence a higher vegetative development and result in increased plant height, with consequent lodging, which negatively interferes with grain yield and quality (Zagonel et al., 2002; Zagonel \& Fernandes, 2007; Penckowski et al., 2009). Among the strategies for using high $\mathrm{N}$ doses, without lodging, are the use of small-size cultivars or application of growth retardants (Penckowski et al., 2010).

Growth retardants are chemicals that have been gaining importance for improving the productive efficiency of cultivated species, being usually used as a control alternative for plant lodging without decreasing grain yield

Submitted on December 14 th, 2019 and accepted on September 28 th, 2020

This work is part of the master's thesis of the first author.

'Universidade Estadual de Londrina, Departamento de Agronomia, Londrina, Paraná, Brazil. josebazzo@uel.br; claudemircca@uel.br; inescbf@uel.br

2Instituto de Desenvolvimento Rural do Paraná - IAPAR-EMATER, Área de Melhoramento Genético, Londrina, Paraná, Brazil. crriede@iapar.br; klever@iapar.br

*Corresponding Author: josebazzo@uel.br 
(Pagliosa et al., 2013). In addition, growth retardants have been used to make plant architecture more adapted and efficient in the use of environmental resources and inputs, which also favors increased productivity and quality of grains (Hawerroth et al., 2015).

The determination of industrial quality of oat grains, which is related to morphological traits that will directly influence the industrial processing (De Francisco et al., 2002), has been carried out by several criteria, namely: hectoliter weight, thousand-grain weight, proportion of grains thicker than two millimeters, and the peeling index (Brasil, 1975). Moreover, the last two parameters, together with grain yield, can define the industrial yield, also called Avenacor (Floss et al., 2002), which expresses the percentage of product obtained for the production of various foods from whole grain samples (CBPA, 2014).

The use of growth retardants and nitrogen fertilization are factors that influence the industrial quality of white oat grains, with variable responses according to edaphoclimatic conditions of the cultivation region. Information on these factors, as well as the interaction between them, about the industrial characteristics of oat grains is scarce.

In this sense, this study aimed to evaluate the industrial quality of grain white oat cultivated under different nitrogen doses and associated with the growth retardant trinexapac-ethyl in two growing environments.

\section{MATERIAL AND METHODS}

The experiments were carried out with the grain white oat cultivar IPR Afrodite (medium cycle, moderate resistance to lodging, and medium height) in two growing environments in the state of Paraná, contrasting regarding edaphoclimatic characteristics: Londrina and Mauá da Serra, PR, Brazil. In Londrina, the experiment was conducted in a eutroferric Red Latosol (Brazillian soil classification system), located at $23^{\circ} 232 \mathrm{~S}$ and $51^{\circ} 112 \mathrm{~W}$, with an altitude of $610 \mathrm{~m}$. The regional climate is Cfa type, described as humid subtropical with hot summers, according to the Köpen climate classification. In Mauá da Serra, the experiment was conducted in a dystroferric Red Latosol (Brazillian soil classification system), located at $23^{\circ} 582 \mathrm{~S}$ and $51^{\circ} 192 \mathrm{~W}$, with an altitude of $847 \mathrm{~m}$. The regional climate is $\mathrm{Cfb}$, described as mesothermal temperate with mild summers, according to the Köpen climate classification. Precipitation and temperature data were obtained from IAPAR weather station records (Figure 1).

Soil chemical characteristics at a depth of 0-20 cm were determined before the experiment was set up in Londrina and were represented by: $5.20 \mathrm{pf} \mathrm{pH}\left(\mathrm{CaCl}_{2}\right) ; 5.55$ $\mathrm{cmol}_{\mathrm{c}} \mathrm{dm}^{-3}$ of $\mathrm{H}+\mathrm{Al}^{3+} ; 4.90 \mathrm{cmol}_{\mathrm{c}} \mathrm{dm}^{-3}$ of $\mathrm{Ca}^{2+} ; 2.73 \mathrm{cmolc}$ $\mathrm{dm}^{-3}$ of $\mathrm{Mg}^{2+} ; 0.80 \mathrm{cmol}_{\mathrm{c}} \mathrm{dm}^{-3}$ of $\mathrm{K}^{+} ; 25.0 \mathrm{mg} \mathrm{dm}^{-3}$ of $\mathrm{P}$; and $16.55 \mathrm{~g} \mathrm{dm}^{-3}$ of organic matter. On the other hand, the following results were obtained for Mauá da Serra: 4.85 of $\mathrm{pH}\left(\mathrm{CaCl}_{2}\right) ; 7.48 \mathrm{cmol}_{\mathrm{c}} \mathrm{dm}^{-3}$ of $\mathrm{H}+\mathrm{Al}^{3+} ; 6.38 \mathrm{cmolc} \mathrm{dm}^{-3}$ of $\mathrm{Ca}^{2+} ; 1.53 \mathrm{cmol}_{\mathrm{c}} \mathrm{dm}^{-3}$ of $\mathrm{Mg}^{2+} ; 0.35 \mathrm{cmol}_{\mathrm{c}} \mathrm{dm}^{-3}$ of $\mathrm{K}^{+} ; 17.5$ $\mathrm{mg} \mathrm{dm}^{-3}$ of P; and $28.82 \mathrm{~g} \mathrm{dm}^{-3}$ of organic matter.

The experimental design for each site was a randomized block in a $4 \times 2$ factorial scheme, with four replications. Treatments consisted of four topdressing $\mathrm{N}$ doses $\left(0,30,60\right.$, and $\left.90 \mathrm{~kg} \mathrm{ha}^{-1}\right)$ and the application or not of the growth retardant trinexapac-ethyl.

The white oat cultivar was mechanically sown under a no-tillage system in an area previously cultivated with soybean in the municipalities of Londrina and Mauá da Serra on May 8, 2014, and May 12, 2014, respectively, with a density of 300 viable seeds $\mathrm{m}^{-2}$. Plots consisted of six rows of five meters in length and interrow spacing of $0.17 \mathrm{~m}$, with a useful area of $5.1 \mathrm{~m}^{2}$.

Base mineral fertilization was carried out in the sowing furrow, being constant for all treatments and based on soil chemical characteristics of the experimental areas, as follows: $30 \mathrm{~kg} \mathrm{ha}^{-1}$ of $\mathrm{N}, 90 \mathrm{~kg} \mathrm{ha}^{-1}$ of $\mathrm{P}_{2} \mathrm{O}_{5}$, and $30 \mathrm{~kg} \mathrm{ha}^{-1}$ of $\mathrm{K}_{2} \mathrm{O}$ in Londrina and $20 \mathrm{~kg} \mathrm{ha}^{-1}$ of $\mathrm{N}, 60 \mathrm{~kg} \mathrm{ha}^{-1}$ of $\mathrm{P}_{2} \mathrm{O}_{5}$, and $20 \mathrm{~kg} \mathrm{ha}^{-1}$ of $\mathrm{K}_{2} \mathrm{O}$ in Mauá da Serra. The formula 1030-10 was used for both growing environments. Topdressing nitrogen fertilization was carried out at a dose of $60 \mathrm{~kg} \mathrm{ha}^{-1}$ of $\mathrm{N}$ as urea $(45 \% \mathrm{~N})$, broadcasted at the tillering stage.

Trinexapac-ethyl was applied at the stem elongation stage, between the 1 st and 2 nd noticeable nodes. The trinexapac-ethyl dose was $125 \mathrm{~g}$ a.i. ha ${ }^{-1}$, which corresponds to $400 \mathrm{~mL} \mathrm{ha}^{-1}$ of the commercial product Moddus $^{\circledR}$, applied with a knapsack sprayer at a constant pressure of $30 \mathrm{lb}$. in ${ }^{-2}$, pressurized by compressed $\mathrm{CO}_{2}$ and equipped with two flat fan spray tips XR 110-020, with a spray solution volume equivalent to $200 \mathrm{~L} \mathrm{ha}^{-1}$.

Management and cultural practices were carried out according to the need and recommendations for the crop (CBPA, 2014). Harvesting was performed after grains reached harvest maturity, a stage characterized by hardening of the caryopsis, plants with dry appearance, and grains with moisture below 20\%. The following evaluations were carried out to determine the industrial quality:

Thousand-grain weight: obtained by counting and weighing eight replications of 100 white oat grains per plot. The mean of these values was multiplied by 10 to obtain the weight of one thousand grains (Brasil, 2009).

Hectoliter weight: determined on a hectoliter scale with a quarter-liter grain capacity. Two replications were taken from the mean sample of the plot. The result was expressed in $\mathrm{kg} \mathrm{hL}^{-1}$ (Brasil, 2009). Hectoliter weight was calculated by the equation: 
$H W=\frac{H S W \times 100}{S V}$

where HW is the hectoliter weight, HSW is the weight obtained on the hectoliter scale $(\mathrm{g})$, and SV is the scale volume $(250 \mathrm{~mL})$.

Grain index greater than two millimeters: determined by sieving a sample of $50 \mathrm{~g}$ of grains per replication on an oblong mesh sieve with two-millimeter-wide holes (Floss et al., 2002). The data were expressed as a percentage (\%) and calculated by the following equation:

$G I>2 \mathrm{~mm}=\frac{G M>2 \mathrm{~mm}}{50} \times 100$

where $\mathrm{GI}>2 \mathrm{~mm}$ is the grain index greater than $2 \mathrm{~mm}(\%)$ and $\mathrm{GM}>2 \mathrm{~mm}$ is the grain mass greater than $2 \mathrm{~mm}(\mathrm{~g})$.

Peeling index: a sample per plot consisting of $50 \mathrm{~g}$ of grains greater than two millimeters was introduced into a laboratory peeler (Codema Inc., USA) for 75 seconds. Caryopses were weighed after peel separation. The data were expressed as a percentage $(\%)$ and calculated by the following equation:

$P I=\frac{C M}{50} \times 100$

where PI is the peeling index (\%) and CM is the caryopsis mass or peeled grains $(\mathrm{g})$.

Industrial grain yield: determined by multiplying grain yield, grain index greater than two millimeters, and peeling index (Floss et al., 2002), being expressed in $\mathrm{kg} \mathrm{ha}^{-1}$ and obtained according to the following equation:

$I G Y=G Y x G I>2 m m x P I$

where IGY is the industrial grain yield, GY is the grain yield, GI > $2 \mathrm{~mm}$ is the grain index greater than $2 \mathrm{~mm}$, and PI is the peeling index.

The data were submitted to the analyses of normality and homogeneity of errors and, subsequently, to the analysis of variance, separately for each growing environment. The means of the growth retardant were
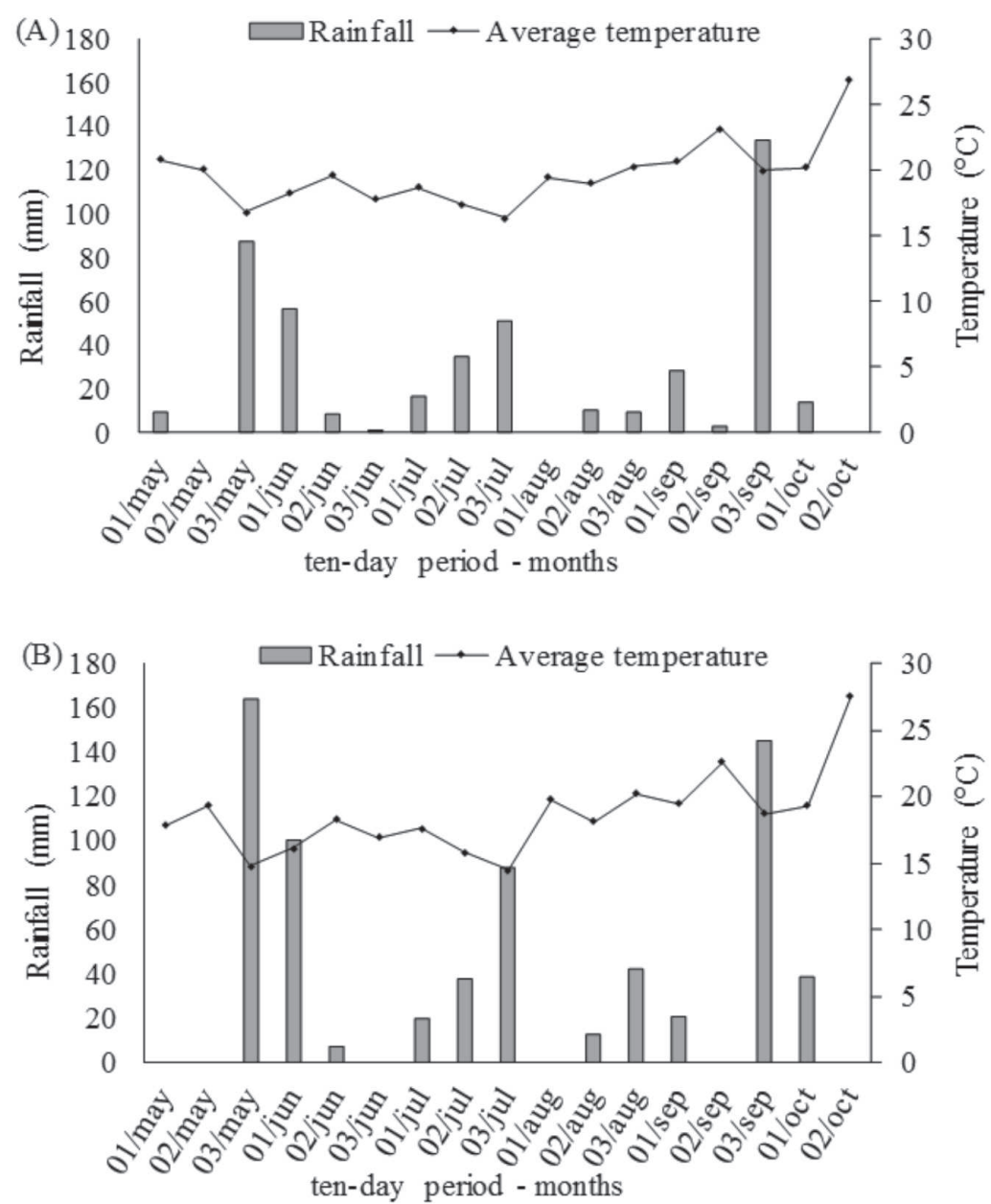

Figure 1: Mean data of temperature and rainfall for 10-day periods during the experimental period in Londrina-PR (A) and Mauá da Serra-PR (B), PR, Brazil. 
compared by the F-test and those of $\mathrm{N}$ doses to a polynomial regression analysis up to $2^{\text {nd }}$ degree, at $5 \%$ significance.

\section{RESULTS AND DISCUSSION}

In Londrina, a significant interaction was observed between the factors growth retardant and $\mathrm{N}$ doses for grain index greater than two millimeters. The traits hectoliter weight and the peeling index had an isolated effect of growth retardant. No effect of growth retardant, $\mathrm{N}$ doses, and interaction between factors was observed for thousand-grain weight and industrial grain yield.

In Mauá da Serra, an effect of the interaction between factors was observed for the variables peeling index and industrial grain yield. A significant effect of growth retardant was found only for the trait grain index greater than two millimeters. No isolated effect of the factors and their interaction was observed for the thousand-grain weight and hectoliter weight.

As shown in Table 1, the application of growth retardant in Londrina reduced the hectoliter weight of grains of the white oat cultivar IPR Afrodite. A possible explanation for this fact would be the production of larger grains, influenced by the use of trinexapac-ethyl, resulting in lower-density grains since their mass was not affected in the cultivation in Londrina, with consequent decrease of hectoliter weight. Degraf et al. (2008) and Souza et al. (2014) evaluated the effect of trinexapac-ethyl on wheat and white oat crops, respectively, and found similar results.

Nascimento et al. (2009) worked with rice, and Penckowski et al. (2010) worked with wheat and verified an increase of hectoliter weight of grains originated from plants sprayed with trinexapac-ethyl, diverging from the results obtained in this study. These authors reported that the positive influence of growth retardant on hectoliter weight could be explained by a reduction in plant height so that the photoassimilates that would be used for plant growth were intended to improve grain filling and hence to result in a higher hectoliter weight.

According to Ordinance $\mathrm{N}^{\circ} .191$ of April 14, 1975, of the Ministry of Agriculture, Livestock and Supply (Brasil,
1975), which establishes the technical regulation of identity and quality of oat grains, grains can be classified into four groups ( 1 to 4 ) based on the hectoliter weight (group 1: $\mathrm{HW}>50 \mathrm{~kg} \mathrm{hL}^{-1}$; group 2: $\mathrm{HW}$ from 47 to $49 \mathrm{~kg}$ $\mathrm{hL}^{-1}$; group 3: HW from 41 to $46 \mathrm{~kg} \mathrm{hL}^{-1}$; and group 4: HW $<41 \mathrm{~kg} \mathrm{hL}^{-1}$ ). As shown in Table 1, the values obtained for hectoliter weight of white oat grains from treatments with and without growth retardant application in Londrina (41.33 and $44.25 \mathrm{~kg} \mathrm{hL}^{-1}$, respectively), fall into the type III classification ( 41 to $46 \mathrm{~kg} \mathrm{hL}^{-1}$ ). Thus, changes provided by the use of growth retardant was not enough to alter the classification and improve grain quality of the white oat cultivar IPR Afrodite.

In Mauá da Serra, the results showed that hectoliter weight of grains was not significantly influenced by the factors of variation in isolation nor by their interaction. Possibly, this result occurred due to the lack of effect of trinexapac-ethyl and $\mathrm{N}$ doses on the yield components number of spikelet per panicle, number of grains per spikelet, and number of grains per panicle. Thus, no competition for nutrients and photoassimilates was observed within the reproductive unit and, therefore, there was no interference on the grain unit mass, not affecting the hectoliter weight of oat grains. Espindula et al. (2010) and Penckowski et al. (2010) worked with the growth retardant trinexapac-ethyl and $\mathrm{N}$ doses in wheat and did not find a significant influence of these factors on hectoliter weight.

The grain index greater than two millimeters of treatments submitted to growth retardant application in Londrina was adjusted to a quadratic function, with the maximum value of this trait $(89.62 \%)$ found at an estimated dose of $24.34 \mathrm{~kg} \mathrm{ha}^{-1}$ of N. However, treatments without the use of growth retardant showed no response of this variable to $\mathrm{N}$ doses (Figure 2). At a dose of $30 \mathrm{~kg}$ $\mathrm{ha}^{-1}$ of $\mathrm{N}$, treatments sprayed with trinexapac-ethyl presented a higher percentage of grains with thickness greater than two millimeters, while at a dose of $90 \mathrm{~kg}$ $\mathrm{ha}^{-1}$ of $\mathrm{N}$, the highest value of this variable was obtained in treatments with no growth retardant. The other doses presented no significant differences between treatments for this trait.

Table 1: Mean values of hectoliter weight (HW) and peeling index (PI) in Londrina and grain index greater than two millimeters (GI $>2 \mathrm{~mm}$ ) in Mauá da Serra of the white oat cultivar IPR Afrodite as a function of the growth retardant trinexapac-ethyl

\begin{tabular}{|c|c|c|c|}
\hline \multirow{2}{*}{ Growth retardant } & \multicolumn{2}{|c|}{ Londrina } & \multirow{2}{*}{$\begin{array}{l}\text { Mauá da Serra } \\
\text { GI > } 2 \mathrm{~mm}(\%)\end{array}$} \\
\hline & HW $\left(\mathrm{kg} \mathrm{hL}^{-1}\right)$ & PI $(\%)$ & \\
\hline Without & $44.25 \mathrm{a}$ & $58.98 \mathrm{a}$ & $94.96 \mathrm{a}$ \\
\hline With & $41.33 \mathrm{~b}$ & $53.68 \mathrm{~b}$ & $92.33 \mathrm{~b}$ \\
\hline $\mathrm{CV}(\%)$ & 2.73 & 10.45 & 1.96 \\
\hline
\end{tabular}

Means followed by the same letter in the column do not differ from each other by the F-test $(\mathrm{P}<0.05)$.

Rev. Ceres, Viçosa, v. 68, n.1, p. 047-054, jan/feb, 2021 
According to Alvarez et al. (2007), who worked with the highland rice cultivar Primavera, the use of trinexapacethyl can interfere with the initial processes of panicle formation, affecting branch formation, the number of spikelets per branches, and floral organs. These authors observed that growth retardant application reduced panicle size, with a probable reduction in the number of spikelets. Thus, growth retardant application in the white oat cultivar IPR Afrodite may have caused the reduction in panicle size and the number of reproductive structures, resulting in a greater balance of photoassimilates for their formation and filling. This fact, together with the greater $\mathrm{N}$ availability, a structural constituent of biomolecules translocated to the panicle during the grain filling period, may have resulted in the formation of well-formed and thicker grains, which justifies the result found for this trait in Londrina.

In Mauá da Serra, the grain index greater than two millimeters was significantly affected by growth retardant application, reducing this variable with the use of trinexapac-ethyl (Table 1). This result may have occurred due to the influence of the growth retardant on the reduction of height and modification of leaf architecture of plants, which probably led to the occurrence of a higher light incidence on them, stimulating the development of fertile tillers and, consequently, the highest number of panicles per $\mathrm{m}^{2}$. Castro \& Kluge (1999) stated that tillering in annual grasses is favored by high light intensity. In this case, increased tillers and reproductive units per area increase the competition in the nutrient and photoassimilate partitioning in plants, hindering the proper grain filling and favoring the formation of thinner grains. The climate characteristics of Mauá da Serra, with milder temperatures than in Londrina, may also have contributed to the higher tiller production. Floss et al. (2009) stated that oat tillering is favored by lower temperatures and stimulated by frost. In this case, the site of cultivation was a factor that influenced the reduction of the grain index greater than two millimeters and may be another justification for the result found in this study.

In Brazil, CBPA (2014) suggested two classification levels for grain index greater than two millimeters: type 1, with at least $75 \%$ of grains greater than two millimeters, and type 2 and 3 , less than $75 \%$ of grains greater than two millimeters. The results found in this study showed that the means of grain thickness produced in the experiments with and without growth retardant application in Mauá da Serra (92.33 and $94.96 \%$, respectively) are significantly higher than the standard type 1 classification suggested by CBPA (2014) (Table 1).

In Londrina, the peeling index was reduced by $9 \%$ due to the use of trinexapac-ethyl in relation to treatments without its application (Table 1). Souza et al. (2014) worked with three grain white oat cultivars (UPFA Gaudéria, UPF 18 , and URS Guria) and four trinexapac-ethyl doses (0, 50, 100 , and $150 \mathrm{~g} \mathrm{a.i.}^{-1}$ ) and found response only for UPF 18 , which showed a quadratic adjustment of the peeling index as a function of the growth retardant doses increment. In this study, the authors observed that the highest percentage of peeled grains $(54.41 \%)$ was obtained at the estimated dose of $60.56 \mathrm{~g} \mathrm{ha}^{-1}$ of the active

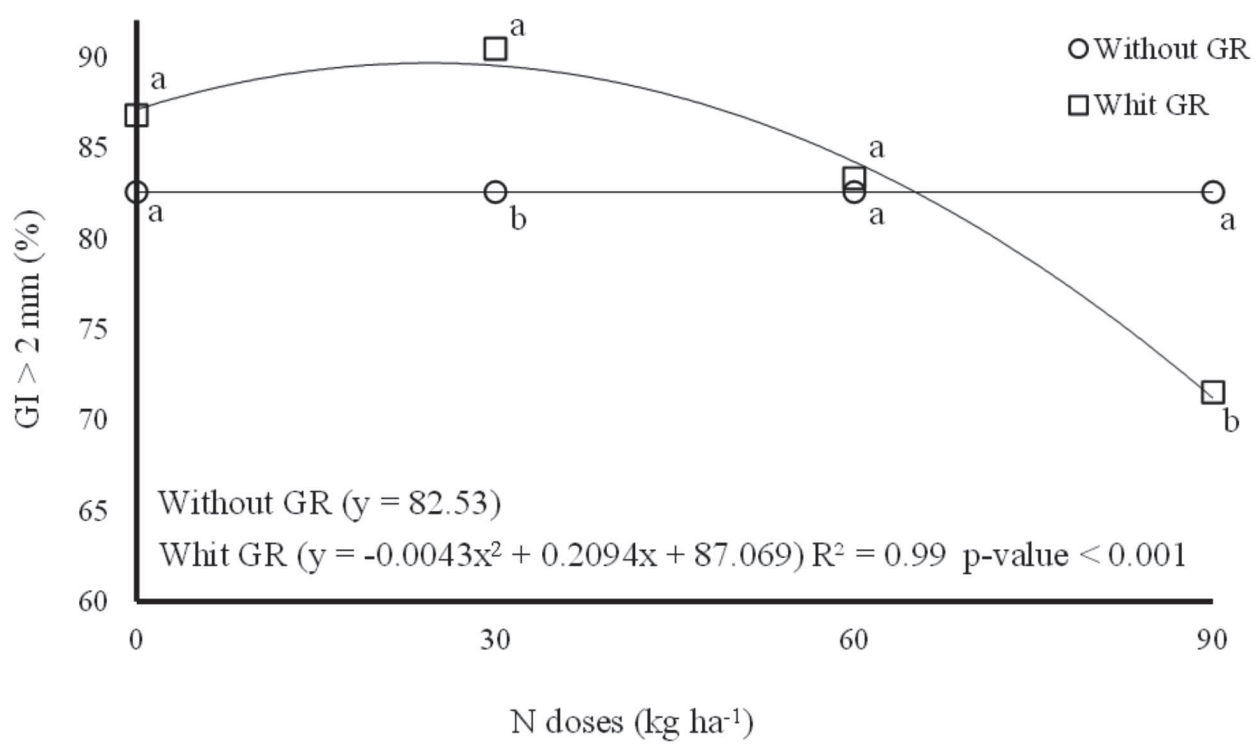

Figure 2: Grain index greater than two millimeters (GI $>2 \mathrm{~mm}$ ) of the white oat cultivar IPR Afrodite as a function of the application of the growth retardant trinexapac-ethyl and topdressing nitrogen doses. Londrina, PR, Brazil. Whit GR (with growth retardant) and Without GR (without growth retardant). 
ingredient. In Londrina, the percentage of peeled grains was not influenced by nitrogen doses, which is similar to that observed by Goi Neto et al. (2015), also working with white oat crop.

The peeling index in Mauá da Serra showed a significant interaction between the factors growth retardant and $\mathrm{N}$ doses, in which treatments without retardant application were adjusted to a quadratic function with the maximum point (72.13\%) obtained at an estimated dose of $58.70 \mathrm{~kg} \mathrm{ha}^{-1}$ of $\mathrm{N}$. However, the percentage of peeled grains from plants submitted to the growth retardant showed no response to $\mathrm{N}$ doses (Figure 3). In the absence of nitrogen fertilization, treatments using trinexapac-ethyl showed higher peeling index, while the other $\mathrm{N}$ doses presented no significant difference between treatments for this variable.

The use of growth retardant and the different nitrogen doses applied in Londrina did not affect the industrial grain yield. Other studies that evaluated the application of topdressing $\mathrm{N}$ doses in white oat crop also found no

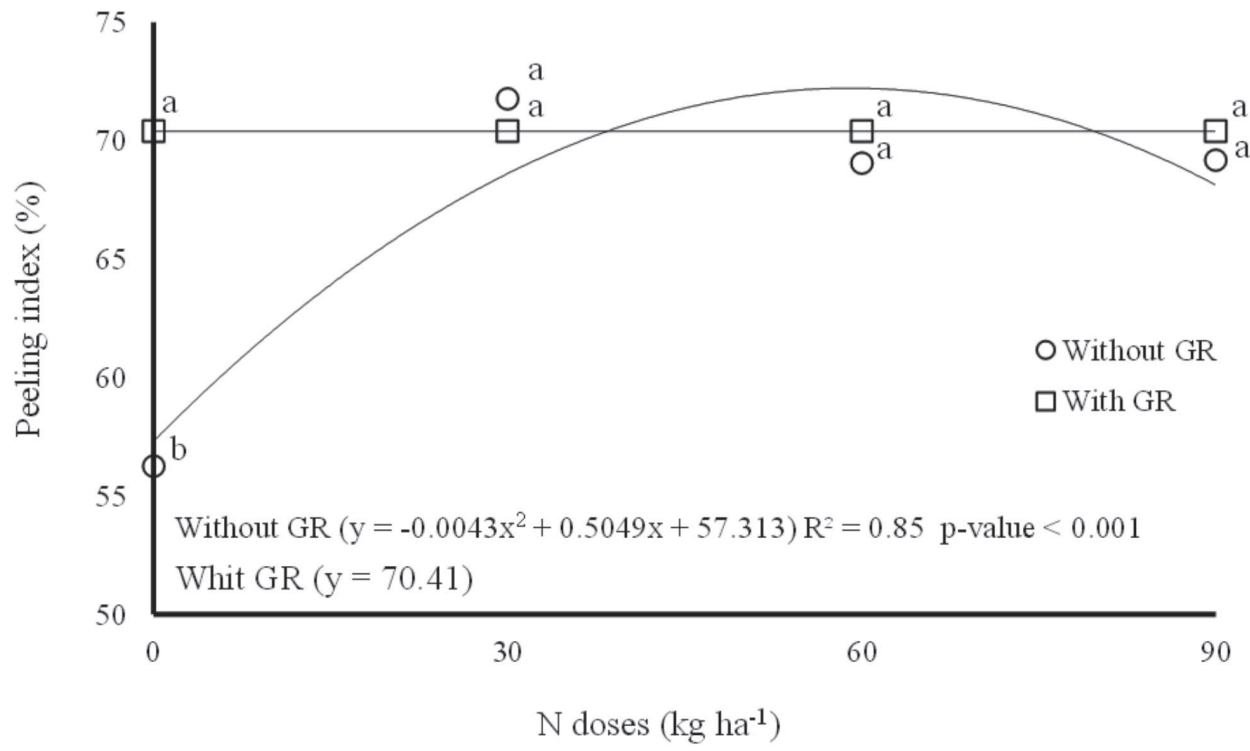

Figure 3: Peeling index of the white oat cultivar IPR Afrodite as a function of the application of the growth retardant trinexapac-ethyl and topdressing nitrogen doses. Mauá da Serra, PR, Brazil. Whit GR (with growth retardant) and Without GR (without growth retardant).

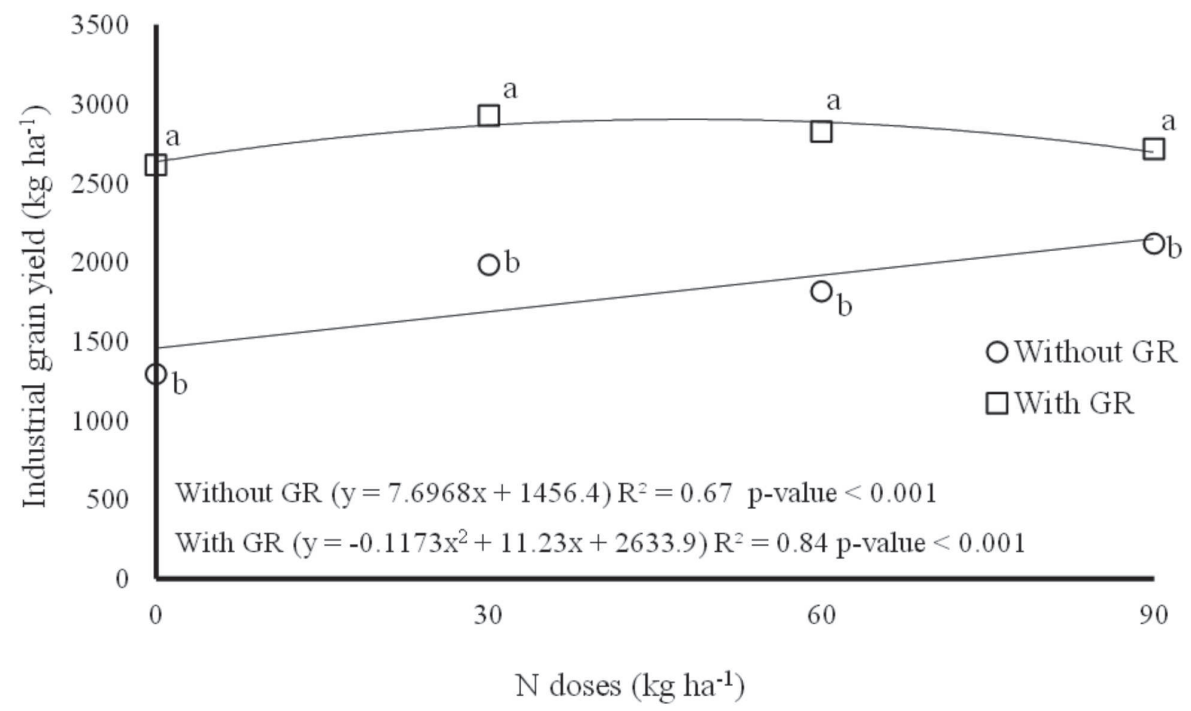

Figure 4: Industrial grain yield of the white oat cultivar IPR Afrodite as a function of the application of the growth retardant trinexapac-ethyl and topdressing nitrogen doses. Mauá da Serra, PR, Brazil. Whit GR (with growth retardant) and Without GR (without growth retardant).

Rev. Ceres, Viçosa, v. 68, n.1, p. 047-054, jan/feb, 2021 
significant response to this parameter (Kolchinski \& Schuch, 2003; Kolchinski \& Schuch, 2004). Cazetta et al. (2006) worked with the rice cultivar IAC 202 and six topdressing $\mathrm{N}$ doses $\left(0,25,50,75,100\right.$, and $\left.125 \mathrm{~kg} \mathrm{ha}^{-1}\right)$ and verified an increase of the industrial grain yield with an increase of $\mathrm{N}$ doses. Regarding the growth retardant, Penckowski \& Fernandes (2014), working with different doses and times of application of the active ingredient trinexapac-ethyl in the white oat cultivars URS Guapa, URS Guria, URS Tarimba, and IAC 7, verified that its application increased the industrial grain yield, but different levels of response were found depending on the dose, application time, or cultivar.

In Mauá da Serra, the industrial grain yield of treatments with and without growth retardant application adjusted to quadratic and linear increasing functions in relation to $\mathrm{N}$ doses, respectively (Figure 4). The maximum value for this trait $\left(1,233.75 \mathrm{~kg} \mathrm{ha}^{-1}\right)$ in the experiment in which plants were sprayed with growth retardant was obtained at the estimated dose of $47.92 \mathrm{~kg} \mathrm{ha}^{-1}$ of $\mathrm{N}$. Treatments with trinexapac-ethyl application had the highest values for industrial grain yield in relation to its absence at all evaluated $\mathrm{N}$ doses.

The higher industrial grain yield obtained in the experiment conducted in Mauá da Serra, when compared to that carried out in Londrina, may have been due to the higher percentages of peeled grains. According to Gatto (2005), industrial grain yield may vary depending on environmental conditions, genotypes, management practices, and year and growing site, which justify the different behavior of the cultivar IPR Aphrodite in both growing sites, as well as when subjected to treatments with and without growth retardant application.

In general, analyses to evaluate the industrial quality of white oat grains of the cultivar IPR Afrodite showed high influence of the growth retardant and the interaction between this factor and $\mathrm{N}$ doses in both growing sites, except for thousand-grain weight, which had no significant effect of the analyzed factors. Experiments that characterized the industrial quality of grains had differences between growing sites, demonstrating the influence of environment on the development of the physical characteristics of grains.

\section{CONCLUSIONS}

The effect of growth retardant and topdressing nitrogen fertilization on the industrial quality of grains of the white oat cultivar IPR Afrodite depends on the characteristics of the growing environment.

The trinexapac-ethyl application reduces grain quality in Londrina and Mauá da Serra. However, the industrial quality of grains is high in both growing sites when the growth retardant is associated with $\mathrm{N}$ doses.

\section{REFERENCES}

Alvarez RCF, Crusciol CAC, Trivelin PCO, Rodrigues JD \& Alvarez ACC (2007) Influência do etil-trinexapac no acúmulo, na distribuição de nitrogênio $\left({ }^{15} \mathrm{~N}\right)$ e na massa de grãos de arroz de terras altas. Revista Brasileira de Ciência do Solo, 31:14871496.

Alves AC \& Kist V (2010) Composição da espigueta de aveia branca (Avena Sativa L.). Revista Brasileira de Agrociência, 16:29-33.

Brasil (2009) Ministério da Agricultura, Pecuária e Abastecimento. Regras para análise de sementes. Secretaria de Defesa Agropecuária. Brasília, DF: Mapa/ACS. 395p.

Brasil (1975) Ministério da Agricultura, Pecuária e Abastecimento. Legislação aplicada à agricultura classificação de produtos vegetais. Portaria Ministerial n. 191 de 14 de abril de 1975.

Castro PRC \& Kluge RA (1999) Ecofisiologia de cultivos anuais: trigo, milho, soja, arroz e mandioca. São Paulo, Nobel. 126p.

Cazetta DA, Arf O, Buzetti S, Sá ME \& Rodrigues RAF (2006) Qualidade industrial do arroz de terras altas cultivado após diferentes coberturas vegetais e doses de nitrogênio em sistema de plantio direto. Científica, 34:155-161.

Ceccon G, Grassi Filho H \& Bicudo SJ (2004) Rendimento de grãos de aveia branca (Avena sativa L.) em densidades de plantas e doses de nitrogênio. Ciência Rural, 34:1723-1729.

De Francisco A, Beber RC, Fulcher RG \& Alves AC (2002) Estudo comparativo de cultivares de aveia (Avena sativa L.) do sul do Brasil: Efeito da morfologia do grão no rendimento industrial. Científica Venezolana, 53:195-201.

Degraf H, Zagonel J \& Fernandes EC (2008) Doses de nitrogênio, regulador de crescimento e programas de controle de doenças afetando a cultivar de trigo Ônix. Ciências Exatas e da Terra, Agrárias e Engenharias, 14:143-152.

Espindula MC, Rocha VS, Souza LT, Souza MA \& Grossi JAS (2010) Efeitos de reguladores de crescimento na elongação do colmo de trigo. Acta Scientiarum Agronomy, 32:109-116.

Floss EL, Haubert AS \& Zanatta FS (2002) Rendimento corrigido pela qualidade industrial de grãos de aveia - Avenacor. In: XXXII Reunião da Comissão Brasileira de Pesquisa de Aveia, Passo Fundo. Anais, Resultados Experimentais/UPF. p.553-558.

Floss EL, Caierão E, Cunha GR \& Pires JLF (2009) Aveia. In: Monteiro JEBA (Ed.) Agrometeorologia dos cultivos: O fator meteorológico na produção agrícola. Brasília, INMET. p.83-90.

Gatto L (2005) Dissimilaridade genética e análise de trilha quanto a características físicas e químicas do grão de aveia branca. Dissertação de Mestrado. Universidade de Passo Fundo, Passo Fundo. 92p.

Goi Neto CJ, Pinto FB, Scremin OB, Mamann ATW, Cardoso AM, Lima ARC, Arnold G \& Silva JAG (2015) O rendimento e qualidade industrial de aveia branca pelo fracionamento de nitrogênio em um sistema de alto N-residual. In: XXXV Reunião da Comissão Brasileira de Pesquisa em Aveia, Porto Alegre. Anais, Resultados Experimentais/UFRGS. CD-ROM.

Hawerroth MC, Silva JAG, Souza CA, Oliveira AC, Luche HS, Zimmer CM, Hawerroth FJ, Schiavo J \& Sponchiado JC (2015) Redução do acamamento em aveia branca com uso do regulador de crescimento etil-trinexapac. Pesquisa Agropecuária Brasileira, 50:115-125.

Kolchinski EM \& Schuch LOB (2002) Produtividade e utilização de nitrogênio em aveia em função de épocas de aplicação do nitrogênio. Revista Brasileira Agrociência, 08:117-121. 
Kolchinski EM \& Schuch LOB (2003) Atributos de desempenho industrial e qualidade de sementes em aveia branca em função da disponibilização da adubação nitrogenada. Ciência Rural, 33:587589

Kolchinski EM \& Schuch, LOB (2004) Relações entre a adubação nitrogenada e a qualidade de grãos e de sementes em aveia branca. Ciência Rural, 34:379-383.

Lângaro NC \& Carvalho IQ (2014) Indicações técnicas para cultura da aveia: XXXIV Reunião da Comissão Brasileira de Pesquisa de Aveia - Fundação ABC. Passo Fundo, Editora Universidade de Passo Fundo. 136p.

Mundstock CM \& Bredemeier C (2001) Disponibilidade de nitrogênio e sua relação com o afilhamento e o rendimento de grãos de aveia. Ciência Rural, 31:205-211.

Nascimento V, Arf O, Silva MG, Binotti FFS, Rodrigues RAF \& Alvarez RCF (2009) Uso do regulador de crescimento etiltrinexapac em arroz de terras altas. Bragantia, 68:921-929.

Pagliosa EE, Benin G, Biezus E, Beche E, Silva CL, Marchese JA \& Martin TN (2013) Trinexapac-ethyl e adubação nitrogenada na cultura do trigo. Planta Daninha, 31:623-630.

Penckowski LH, Zagonel J \& Fernandes EC (2009) Nitrogênio e redutor de crescimento em trigo de alta produtividade. Acta Scientiarum Agronomy, 31:473-479.
Penckowski LH, Zagonel J \& Fernandes EC (2010) Qualidade industrial do trigo em função do trinexapac-ethyl e doses de nitrogênio. Ciência e Agrotecnologia, 34:1492-1499.

Penckowski LH \& Fernandes EC (2014) Época de aplicação e dose para o regulador de crescimento trinexapac-ethyl em cultivares de aveia-branca. In: XXXIV Reunião da Comissão Brasileira de Pesquisa de Aveia, Castro. Anais, Resultados Experimentais/Fundação ABC. CD-ROM.

Souza CA, Sponchiado JC, Correa C, Mendes M, Tormem ME, Lângaro NC \& Pacheco MT (2014) Desempenho agronômico e qualidade industrial de cultivares de aveia branca em função de doses de trinexapac-ethyl. In: XXXIV Reunião da Comissão Brasileira de Pesquisa de Aveia, Castro. Anais, Resultados Experimentais/Fundação ABC. CD-ROM.

Zagonel J, Venancio WS, Kunz RP \& Tanamati H (2002) Doses de nitrogênio e densidades de plantas com e sem um regulador de crescimento afetando o trigo, cultivar OR-1. Ciência Rural, 32:25-29.

Zagonel J \& Fernandes EC (2007) Doses e épocas de aplicação do regulador de crescimento afetando cultivares de trigo em duas doses de nitrogênio. Planta Daninha, 25:331-339. 